\title{
Management of the Education Cost from Community Participation
}

\section{Ratna Heny Kumalawati and Udik Budi Wibowo}

Postgraduate Program, Yogyakarta State University

\section{Abstract}

In the implementation of education, community participation has been regulated in the Law of the Republic of Indonesia No. 20 of 2003, so that the management of the cost from community or parents of students is necessary. The focus of the research is the management of the education cost from community. The research problems are formulated as follow: How is the plan for school revenue and expenditure; How is the expenditure on the education cost, and; How is the reporting and responsibility for the education cost. The purpose of the research was to obtain information about the management of the education cost from community participation. This research used a descriptive qualitative approach. The data were collected through observation,

Corresponding Author: Ratna Heny Kumalawati ratnahk@yahoo.com

Received: 2 May 2019 Accepted: 19 June 2019 Published: 3 July 2019

Publishing services provided by Knowledge E

(c) Ratna Heny Kumalawati and Udik Budi Wibowo. This article is distributed under the terms of the Creative Commons

Attribution License, which permits unrestricted use and redistribution provided that the original author and source are credited.

Selection and Peer-review under the responsibility of the ICMEd Conference Committee. documentation studies, and interviews. The result shows that the preparation of the School Revenue and Expenditure Plan is included in a participatory category, and the budgets are sourced from the parents of students through intensive communication with them, endowment for school development, and extracurricular activities cost. The conclusion shows that the preparation of the School Revenue and Expenditure Plan has been carried out in a participatory manner.

Keywords: Management, Education Cost, Community Participation

\section{Introduction}

Community participation in the administration of education has been mandated in the Law on the National Education System Article 8, that the community has the right to participate in the planning, implementation, supervision, and evaluation of educational programs [1]. One significant variable in management is fee [2]. There are four principles in the management of education cost, one of which is accountability that the community has the right to know the endowment to the school, both the effectiveness and efficiency. Therefore, the management of the education cost from community or parents of students is necessary. Financial management is an activity in managing finance by utilizing existing resources to achieve goals effectively and efficiently [3]. This activity includes planning, implementation, and accountability. 
In preparing School Revenue and Expenditure Plan, the principal forms a team consisting of teachers and school committee. Then, the team and the principal make and detail all the school revenue and expenditure, which later the principal agrees to. The involvement of teachers and school committee certainly resulted in a sound plan, and the school will be responsible for implementing it. The school cost is sourced from the government and community, as well as the business world [4]. The implementation or process of using the cost is a management function that can be interpreted as a management effort to realize all plans to achieve organizational goals through the use, utilization, and direction of all organizational resources [5]. Accountability is a form of transparency in financial management. The principal must make a report in verifying the progress of an activity by recording, detailing, and inputting budgetary sources [6]. Revenue and expenditure for education must be reported regularly in accordance with the applicable rules. The reporting and accountability of the cost from parents and community must be carried out in a detailed, transparent manner in accordance with the sources of the funds.

This research was focused at understanding the empirical reality of the management of the education cost from community participation in Stella Duce Senior High School of Bantul. The research problems are formulated as follow: (1) how is the plan for school revenue and expenditure? (2) how is the expenditure of the education cost from community? (3) how is the reporting and responsibility for the education cost from community? The research was aimed at obtaining information about the management of the education cost from community participation.

\section{Material \& Methodology}

This research used a descriptive method with a qualitative approach and was taking place at Stella Duce Senior High School of Bantul. The data sources were determined using a purposive sampling method. The data collection techniques used observation, interviews, and documentation studies. The data in this research were validated through triangulation technique with sources by comparing the data from interviews with the data from observations and documentation. For data analysis, this research used an interactive analysis model. 


\section{Results and Discussion}

The preparation of School Revenue and Expenditure Plan of Stella Duce Senior High School of Bantul was conducted in three stages, namely stage I, stage II, and stage of making the School Revenue and Expenditure Plan for foundation, and it has involved the school components. The preparation included evaluating the program, forming the group and coordinator, identifying the needs and sources of the cost, identifying the activities, and establishing the plan.

The preparation of the School Revenue and Expenditure Plan of Stella Duce Senior High School of Bantul is considered participatory. The preparation used a balanced approach between revenue and expenditure. The plan comprises all activities in one school year, consisting of several sources of education cost, activities plan of which the activities are executable and affordable, and it involves all school components. The sources of cost from the community include socialization and implementation of activities in the School Budget and Activities Plan as a form of responsibility to the community. The efforts made to include community, among others: constantly involve parents in school activities in professional manner; establish intensive communication with parents of students (e.g. joint worship activities); involve parents in various social activities in schools, and; provide consulting service for students. In managing the revenue of sources of cost, the school applies bookkeeping. The book contains the endowers' name, the class, the purpose of payment, and the amount of money endowed. Every incoming fee is then recapitulated.

The efforts made by Stella Duce Senior High School of Bantul was in accordance with the criteria in involving community participation, even the other schools nearby did not do the same. The forms of cost obtained from parents (community) namely tuition, activities cost, extracurricular activities cost, new student registration cost, and school uniforms cost. Cost for student learning facilities, building construction, and tuition are the cost obtained from parents [7]. The flow to use the cost from community comprises: a proposal coming from the school, then it gets approval from the principal as the manager of the cost from community or parents. The School Activities and Budget Plan-that has been established as the School Revenue and Expenditure Plan for foundation by the principal-is used as a guideline in budget use. The cost from community is allocated to several school and non-school programs. For bookkeeping, the budget from community, i.e. all transactions both revenues and expenditures must be recorded as the procedure, the accounting period is closed at the end of each month. 
The bookkeeping of budget usage from parents conducted in Stella Duce Senior High School of Bantul uses the foundation rules, but is guided by the bookkeeping of the School Operational Assistance in order to simplify and ease the treasurer in financial records. In addition, it also has a recapitulation of the use of cost, notes, expenditure receipts, and attachments to the expenditures of cost.

The supervision is carried out continuously and periodically. The supervision of the management of the cost from community is carried out by the principal, school committee, foundation, and the government. The steps in supervision and control carried out by the foundation and committee in the use of the cost have met the standards of supervision measures, this is because the control is carried out by determining standards that will be used as the basis of control, measuring implementation, comparing implementation and determining deviations if any, and taking corrective actions in accordance with the plan [8]. As the results, Stella Duce Senior High School of Bantul is considered has steps that lead to a transparent, accountable, effective and efficient management of cost.

For reporting and accountability of revenue and expenditure from community, the treasurer reports to the principal and school committee, then they present the report to the parents of students. In addition, the principal also presents the financial condition to the teachers and staffs at the end of each month. Thus, those who receive the report on the use of the cost from parents or community are the principal, foundation, school committee, and parents of students. For other parties concern with the financial reporting, the school will provide it as necessary. The report made by Stella Duce Senior High School of Bantul consists of a cash book and expenditures receipts. The report is usually presented quarterly, semesterly, and yearly. The reporting forms are both written and oral.

\section{Conclusion}

The preparation of School Revenue and Expenditure Plan conducted in Stella Duce Senior High School of Bantul has been carried out in a participatory manner. The education cost from community or parents of students and foundation are very significant. The education cost from community is allocated to several school and non-school programs. Supervision and control of the education cost from community have been carried out according to the provisions of supervision. The reporting and accountability of the education cost from community or parents of students have been carried out in accordance with regulations regarding public sector budget reporting. 


\section{References}

[1] Republik Indonesia. Undang-undang RI No 20 tahun 2003, tentang Sistem Pendidikan Nasional, http://kemenag.go.id/file/dokumen/UU2003.pdf Retrieved March15, (2018).

[2] Fitz-enz, J., "The ROI of Human Capital: Measuring the economical value of employee performance,"New York: AMACOM American Management Association, (2009).

[3] Gunawan, I., Benty, D. D. N., "Manajemen Pendidikan: Suatu Pengantar Praktik," Bandung: Alfabeta, (2017).

[4] Akdon., Kurniady, D. A., Darmawan, D., "Manajemen Pembiayaan Pendidikan," Bandung: Remaja Rosdakarya, (2015).

[5] Werang, B. R., "Manajemen Pendidikan di Sekolah," Yogyakarta: Media Akademi, (2015).

[6] Muryati, I., "Pengelolaan Dana BOS pada SD Negeri di UPT Pelayanan Pendidikan Kecamatan Moyudan Kabupaten Sleman,", Jurnal Akuntabilitas Manajemen Pendidikan, 4(2), (2016).

[7] Dirjen PMPTK..,"Manajemen Peran serta Masyarakat dalam Pengembangan Pendidikan Sekolah," Departemen Pendidikan Nasional, (2007).

[8] Hasibuan, H. M., "Manajemen, Dasar, Pengertian, dan Masalah," Jakarta: Bumi Aksara, (2009). 